\title{
Identification of systems tracts in low-angle carbonate ramps: examples from the Upper Jurassic of the Iberian Chain (Spain)
}

\author{
Marc Aurell * \\ Departamento de Geologia, Universidad de Zaragoza, 50.009-Zaragoza, Spain
}

Received February 26, 1991; revised version accepted June 25, 1991

\section{ABSTRACT}

Aurell, M., 1991. Identification of systems tracts in low-angle carbonate ramps: examples from the Upper Jurassic of the Iberian Chain (Spain). Sediment. Geol., 73: 101-115.

The Upper Jurassic of the Iberian Chain in northeast Spain was selected for the study and identification of sequence boundaries and systems tracts in low-relief carbonate ramp systems. The study area provides a special opportunity for sequence stratigraphic analysis because the outcropping Upper Jurassic carbonate ramps are relatively undeformed, well-exposed from proximal to distal areas and have an established ammonite zonation. Two sequences are recognized. Sequence $\mathrm{A}$, uppermost Callovian to uppermost Oxfordian in age (up to $60 \mathrm{~m}$ thick in the proximal areas and between 15 and $5 \mathrm{~m}$ thick in the middle and distal areas), and Sequence B, Kimmeridgian to lowermost Tithonian (from 80 to $160 \mathrm{~m}$ in thickness across the basin). The evolution of the first sequence is related to regional relative sea-level changes, i.e., tectono-eustatic changes superimposed on the sedimentary basin. On the other hand, the larger accommodation created during the second sequence is regarded as controlled mainly by steady subsidence.

Sequence boundaries indicative of subaerial exposure show as unconformities with stratigraphic hiatuses in the proximal areas of the basin. The lowstand systems tract in Sequence A is represented by a decimetre-thick reworked level, consisting of several ammonite biozones. In Sequence B, this systems tract consists of a thick, wedge-shaped, marly unit. In both sequences, the transgressive surface overlaying these lowstand deposits is generally planar and marks a sharp boundary between the restricted and open marine fossils. However, in Sequence B, in the middle part of the basin, the transgressive surface can be absent; instead a transitional change to open marine facies exists. The transgressive systems tracts show sedimentary condensation at least in the distal areas of the basin with mostly ammonites and benthic fossil wackestones. The transgressive unit is generally overlain by a hard ground surface that corresponds to a maximum flooding surface. Finally, in the upper part of both sequences, highstand systems tracts are represented by progradational siliciclastic and shallow carbonate complexes in the proximal areas of the basin. In Sequence A, sedimentation is condensed in the distal areas with glauconite marl levels present.

The descriptions of sedimentary features of the systems tracts of these two sequences, developed in a low-angle carbonate ramp, are suggested to be used as tools for the recognition of systems tracts patterns within sequences in comparable depositional settings.

\section{Introduction}

The sequence stratigraphy as a tool in the analysis of sedimentary basins was developed during the 1960s and 1970s and refined and accepted as a concept in the early 1980s (Vail et al., 1977; Haq et al., 1987). The identification of sequences is

\footnotetext{
* Present address: R.S.M.A.S./M.G.G, University of Miami, 4600 Rickenbacker Csw, Miami, FL 33149, U.S.A.
}

mainly based on the recognition of subtle differences in the dip of seismic reflectors or bedding planes. The fundamental unit of sequence stratigraphy is the sequence, which is bounded by unconformities or their correlative conformities. The term systems tract is used to designate three subdivisions within each sequence: lowstand-, transgressive- and highstand-systems tracts. These subdivisions are defined on the character of their bounding surfaces, their position within a sequence and the parasequence set stacking pat- 
terns. Systems tracts are also characterized by geometry and facies associations. Lowstand systems tract bounding surfaces are the sequence boundary and the transgressive surface. The top of the transgressive systems tract is the downlap surface or maximum marine flooding surface. The condensed section, occurring between the transgressive and distal highstand systems tract, is a facies consisting of thin marine beds of hemipelagic or pelagic sediments deposited at very slow rates. The subdivision into systems tracts provides a powerful tool for documenting the history of the basin, emphasizing the role played by factors as synsedimentary tectonics, subsidence, eusticy, and sediment supply rates or carbonate production.

Sequence stratigraphy as a concept has been used in the study of numerous outcrop examples of high-rising rimmed carbonate platform systems, with well-defined geometric relations between the different sequences (e.g. Sarg, 1988). Carbonate ramps and epeiric carbonate platforms, i.e. extensive and low-angle depositional areas covered by very shallow seas, are common in the geologic record. In these depositional settings, geometric criteria fail because of the negligible topography. Recently, predictive models and documentation of systems tracts distribution in carbonate ramps have been proposed by Van Wagoner et al. (1988) and Calvet et al. (1990).

In this report, the Upper Jurassic of the Iberian Chain of northeast Spain serves as an example to illustrate the identification of systems tracts by the analysis of the bounding surfaces and facies associations across the proximal, middle and distal areas of the basin. Detailed outcrop studies, the measurement of 65 stratigraphic sections (Fig. 1) and the lateral tracing of sedimentary units and bounding surfaces, form the basis of this study. Age determinations and correlations were made using standard ammonite biozonations. The time scale used is that of Haq et al. (1987). Major facies types were assessed by interpretation of depositional settings in outcrop and from petrographic studies according to published standard works on facies reconstruction (e.g., Wilson, 1975; Flügel, 1982; Scholle et al., 1983).

The Oxfordian and Kimmeridgian deposits in the central part of the Iberian Chain, offer good conditions for the sequence-stratigraphy approach. First, excellent outcrop conditions and the apparent undisturbed overall geometry, as evidenced by the great lateral extent and continuity of the Oxfordian and Kimmeridgian ramps, allowed the study of two transverse sections from the proximal to the distal areas. Second, the presence of well-defined ammonite biozones supplied an accurate age frame.

\section{The Upper Jurassic of the Iberian Chain}

This study focuses on the Upper Jurassic outcrops located in the central part of the Iberian Chain (northeast Spain). During the Upper Jurassic, in the northeastern part of the Iberian Peninsula, sedimentation took place in shallow epicontinental seas, with a predominance of carbonate sedimentation in laterally extensive ramp settings (Bulard, 1972; Salas, 1990; Aurell, 1990). Previous work on the sequence-stratigraphy analysis of this low-relief carbonate ramp system was published by Aurell et al. (1990a) and Aurell (1990). Studies on carbonate systems of identical age and setting in adjacent areas, were published by Salas $(1987,1990)$, in the eastern Iberian Chain and Catalanides, and Alonso and Mas (1990), in the northwestern Iberian Chain.

According to Salas (1987), the Upper Jurassic consists of three depositional sequences, separated by laterally correlatable unconformities. This report deals with the two lowermost sequences, both deposited in a ramp setting with carbonate facies prevailing. Some selected stratigraphic sections across the basin, including the materials of these two sequences, are shown in Fig. 1. The lowermost Sequence A (or Oxfordian) developed during the uppermost Callovian to uppermost Oxfordian, whereas Sequence B (or Kimmeridgian) was deposited during the Kimmeridgian and lowermost Tithonian (Fig. 2).

The geological time covered by both sequences is similar, approximating $7 \mathrm{Ma}$, and they are larger than the third-order cycles proposed by Haq et al. (1987) for the identical stratigraphic interval. However, there is a remarkable difference in the thickness of the two sequences. The Oxfordian Sequence (A) is relatively thin, with up to $60 \mathrm{~m}$ in 

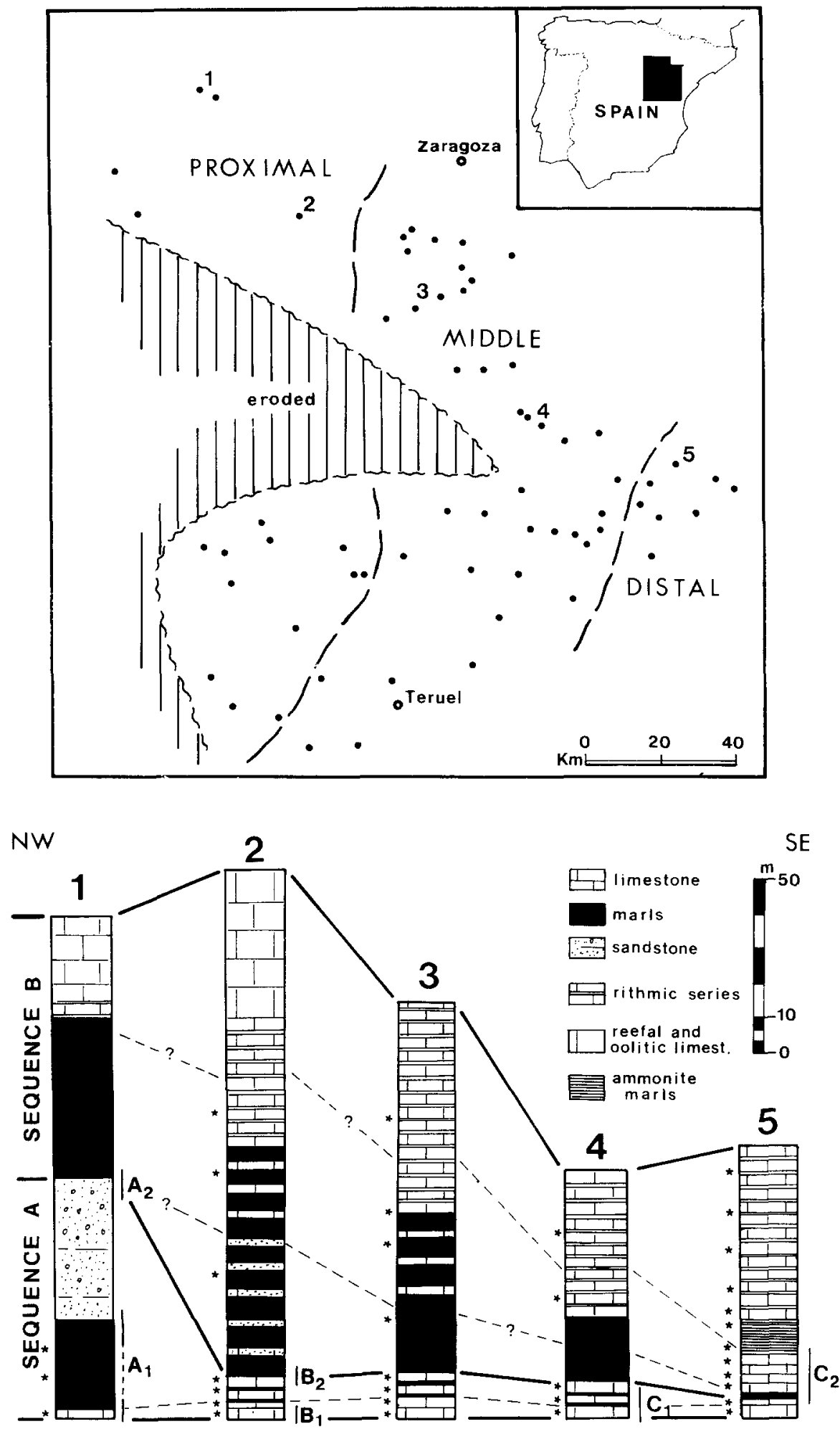

Fig. 1. Locality map showing the studied sections and the distribution of the proximal, middle and distal domains of the Upper Jurassic ramps. The selected sections display the main lithologic features of the Oxfordian and Kimmeridgian Sequences (A and B, respectively). Continuous lines indicate sequence boundaries, whereas dashed lines show the systems tracts boundaries. Asterisks in the left side of these sections mark the presence of well-defined ammonite biozones. Segments in the right side indicate the position of the more detailed sections showed in Figs. 3 and 4 ( $A_{1}$ to $C_{1}$ and $A_{2}$ to $C_{2}$, respectively). 


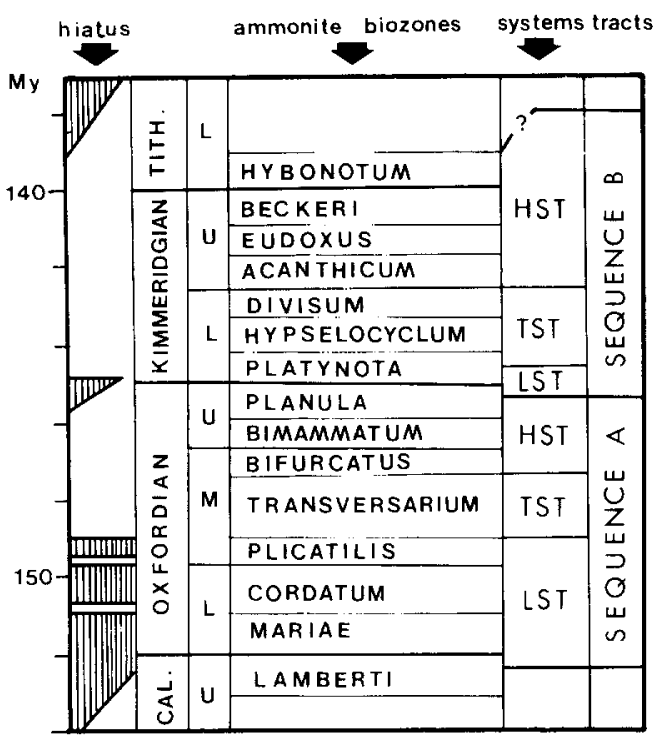

Fig. 2. Stratigraphic units, ammonite biozones and interpreted systems tracts distribution. Left column shows the extend of the ammonites hiatuses. $L S T=$ lowstand systems tract, $T S T=$ transgressive systems tract, $H S T=$ highstand systems tract.

the proximal areas and between 15 and $5 \mathrm{~m}$ thick in the middle and distal areas, whereas the Kimmeridgian Sequence (B) is thicker, from 80 to 160 $\mathrm{m}$ thick across the basin. This difference is suggested to be a function of the rate of creation of accommodation space, being the combined result of the rates of eustacy and subsidence.

\section{Systems tracts distribution}

According to the philosophy of sequence stratigraphy, these two sequences are related to two complete sea-level cycles. Sequence boundaries are produced at the inflection points of the sealevel falls. The documentation of the facies distribution across the basin and their correlation supported by an accurate biostratigraphic framework, allow us to propose the subdivision of these two cycles in their lowstand, transgressive and highstand deposits. Schematic transverse cross-sections for both sequences, from western proximal to eastern distal areas are based on the variance in thickness of units across the basin (Figs. 3 and 4). The measured sections represented in the lower part of these figures display the lithofacies recognized in several parts of the basin around the sequence and systems tracts boundaries. Figures 5 and 6 illustrate the distribution of some of these boundaries in two selected sections.

\section{Oxfordian Sequence}

\section{Sequence boundary and lowstand system tract}

\section{Field data}

The lower Oxfordian Sequence boundary is an unconformity with an associated stratigraphic hiatus affecting, at least, two Callovian-Oxfordian boundary ammonite biozones (see Bulard, 1972; Meléndez and Brochwicz-Lewinskii, 1983). This unconformity, a highly irregular surface of low vertical development (Fig. 3B), has also been described from more proximal areas, in the northwestern Iberian Chain (Alonso and Mas, 1990). Stromatolites locally occur on this uneven surface. Covering this surface, there is a 0.1 to $0.2 \mathrm{~m}$ micritic level containing lithoclasts, scattered marine benthic fossils and ammonites from the lower Cordatum and Plicatilis biozones (i.e., fossils of the Claromontanus and Paturattensis subzones: Meléndez et al., 1990). Thus, this level implies several ammonite hiatuses (left column in Fig. 2). The ammonites are generally preserved as inner calcareous or phosphatic fossil moulds with ferruginous crusts and truncational and erosional features.

In the eastern areas, the hiatus represented by this lower sequence boundary is substantially larger. This unconformity is a planar and truncational surface, overlaying Middle Bathonian oolitic limestones (Fig. 3D). The first record of Oxfordian deposits on this unconformity are bioclastic facies (skeletal packstones) from the Transversarium biozone, the Callovian and the Lower Oxfordian sediments being absent. This area acted as a sedimentary high during the Callovian-Oxfordian boundary (i.e. "Ejulve high", Bulard, 1972).

The lower micritic level locally contains ferruginous pisoids and ooids (Fig. 3C). The mineralogical composition of these ooids is goethite with traces of kaolinite. Facies with poorly sorted ooids and pisoids (wackestones with scattered ammonites) are found around the eastern sedimentary high, while facies with well-sorted ferruginous ooids (generally packstones with ammonites and 


\section{Sequence $A$}

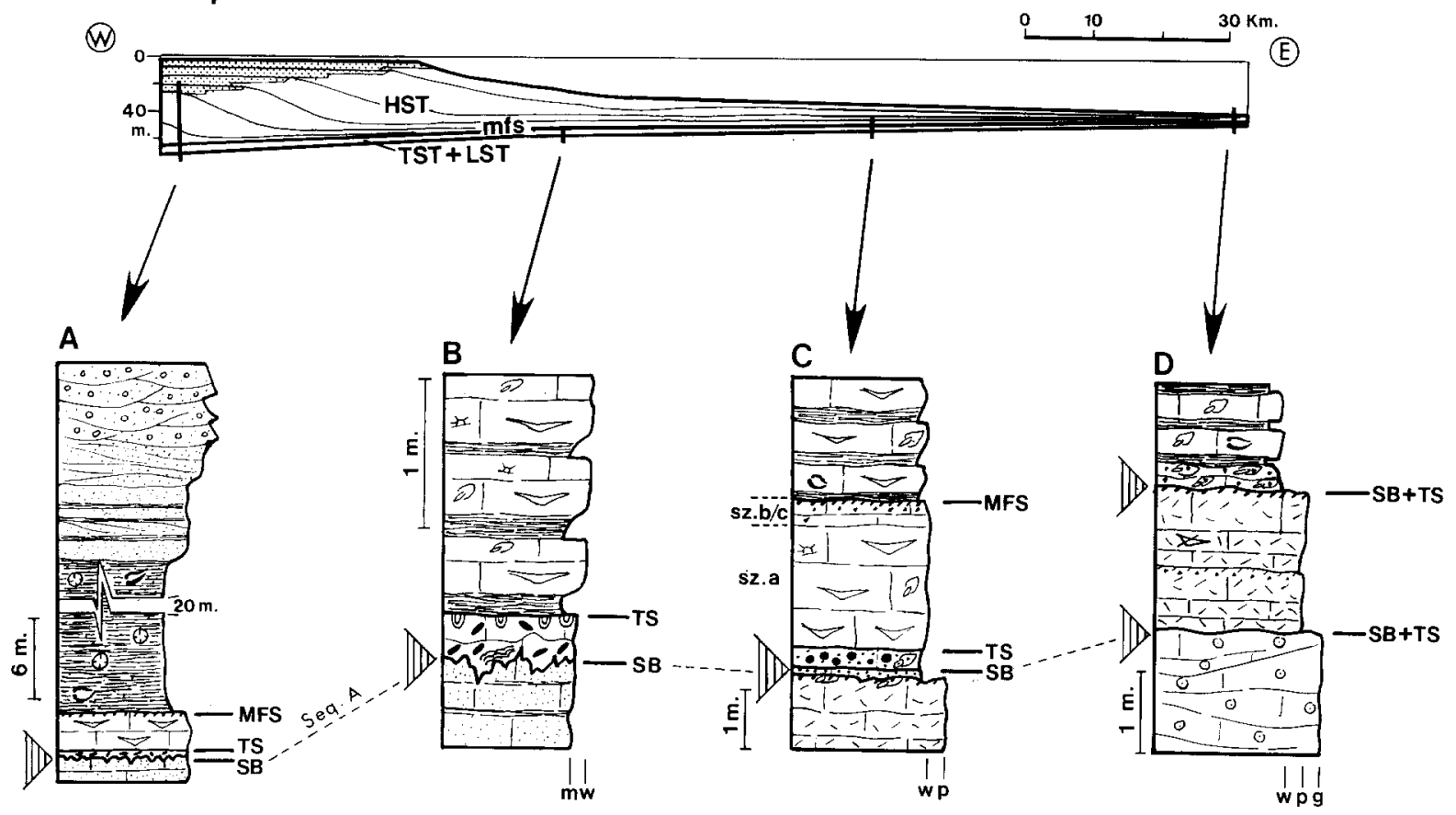

\begin{tabular}{|c|c|c|c|c|c|c|c|c|}
\hline 6 & ammonites & $\ominus$ & crinoids & $\approx$ & stromatolites & $m$ & $\begin{array}{l}\text { hard ground } \\
\text { \& Fe crust }\end{array}$ & D hiatus \\
\hline$\Theta$ & aherm. corals & $D$ & echinoids & 3 & bioclasts & Wh & karst & sz. subzone \\
\hline 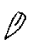 & belemnites & & plants remains & प & Diplocraterion & ب: & Fe ooids and pisoids & bz, biozone \\
\hline 0 & bivalves & $\approx$ & sponges & $\pi$ & borings & 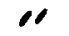 & reworked molds & siliciclastics \\
\hline
\end{tabular}

Fig. 3. Section showing the interpreted systems tract distribution in the Oxfordian Sequence. This section was constructed taking into account the decompacted thickness across the basin (see Aurell, 1990). Selected measured sections display some of the main features observed around the systems tracts bounding surfaces (their position indicated in the sections of Fig. 1). LST $=$ lowstand systems tract, $T S T=$ transgressive systems tract, $H S T=$ highstand systems tract, $S B=$ sequence boundary, $T S=$ transgressive surface, $M F S=$ maximum flooding surface. Vertical exaggeration $\times 200$.

brachiopods) prevail in the middle areas of the basin (Aurell et al., 1990b; Meléndez et al., 1990).

\section{Interpretation}

The uneven basal surface represents the lower boundary of the Oxfordian Sequence and is interpreted as a karstic surface as evidenced by a period of substantial subaerial exposure. During the lower Cordatum and Plicatilis chronozones, two periods of punctuated flooding of the ramp resulted in the deposition of ammonites, mainly as drifted conchs. Eastern areas which remained emerged during this phase, are explained as topographic highs not within reach of these minor sea-level changes (i.e. Ejulve high). Therefore, these two flooding events are interpreted as higher-order sea-level highstands. The included ammonite hiatuses during this lowstand episode correspond to very shallow subtidal to supratidal depositional conditions, favoring reworking of the sediment (Meléndez et al., 1990). The local presence of ferruginous ooids and pisoids is additional evidence for subaerial exposure (e.g. pedogenetic processes as those described in Nahon et al., 1980), 


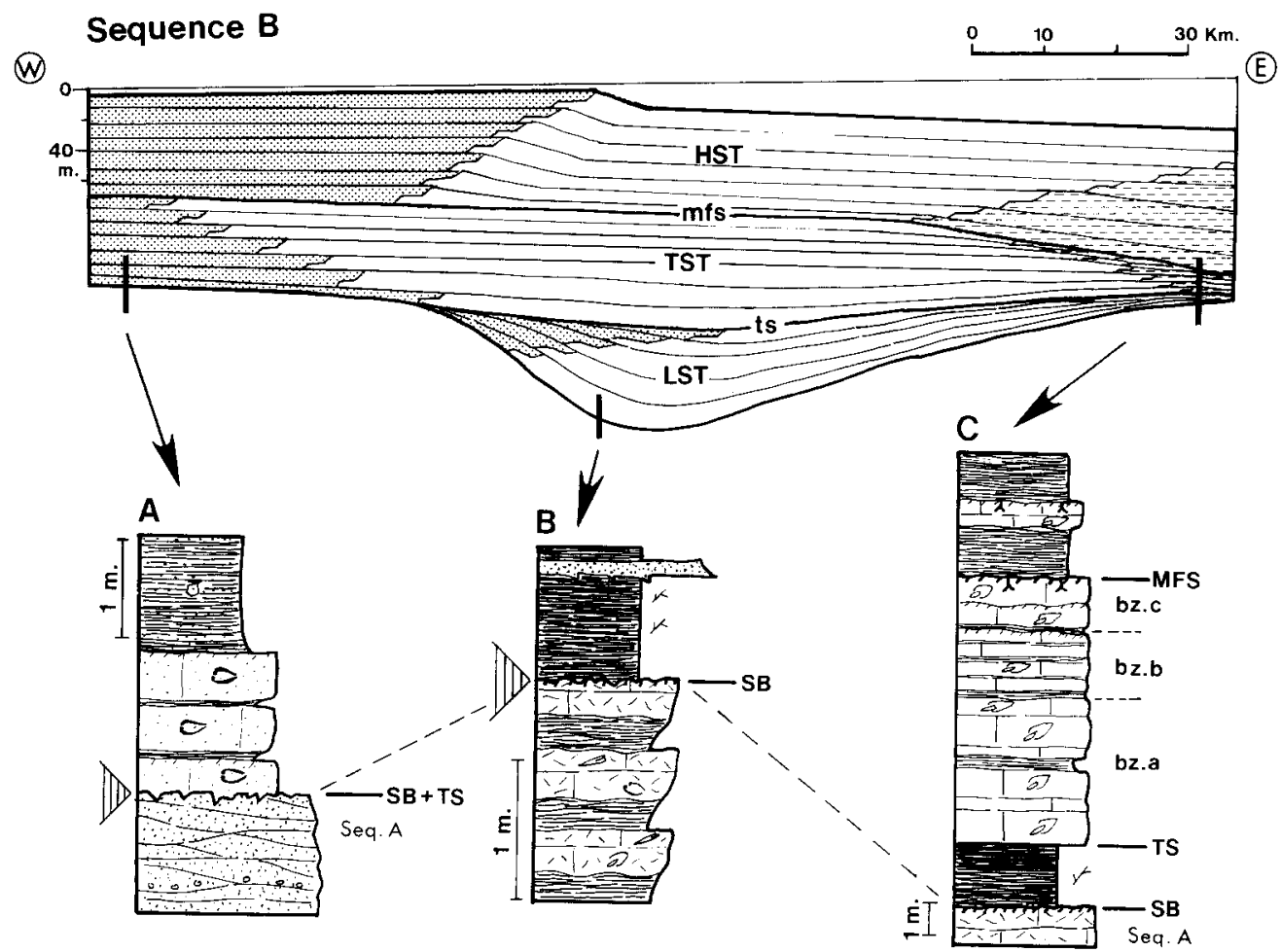

Fig. 4. Section showing the interpreted systems tract distribution in the Kimmeridgian Sequence. This section was constructed taking into account the decompacted thickness across the basin (see Aurell, 1990). Selected measured sections display some of the main features observed around the systems tracts bounding surfaces (their position indicated in the section of Fig. 1). See Fig. 3 for legend. $L S T=$ lowstand systems tract, $T S T=$ transgressive systems tract, $H S T=$ highstand systems tract, $S B=$ sequence boundary, $T S=$ transgressive surface, $M F S=$ maximum flooding surface. Vertical exaggeration $\times 200$.

as they may have been redistributed across the basin during the flooding episodes (Siehl and Thein, 1978; Aurell et al., 1990b).

\section{Transgressive surface and transgressive systems tract}

\section{Field data}

The discontinuous micritic reworked level with ferruginous ooids of the bottom of the Oxfordian Sequence, can be overlapped by a burrowed planar surface with Diplocraterion traces (Fig. 3B). Over the basal reworked level, a fossil wackestones facies is present extending across the entire basin and representing the Transversarium biozone. It consists of wackestones with sponges, ammonites, echinoids, ahermatypic corals, belemnites, bivalves, benthic and planktonic forams, in a thickness between 2 and $5 \mathrm{~m}$. Several stacked ammonite assemblages allow an accurate biostratigraphic subdivision into this biozone. Fontana and Meléndez (1990) found evidence for a decrease of thickness towards the top of this biozone

Fig. 5. Interpretation of systems tracts distribution in the Ricla section (i.e., section 2 in Fig. 1). (A) General view of the section, showing the systems tracts distribution in Sequence B. The lowstand systems tract ( $L S T)$ consists of sandy marls and interbedded sandstones. The transgressive systems tract (TST) is composed of marls and interbedded limestones at the bottom and, towards the top, of a rhythmic alternation of marls and sandy limestones. This rhythmic lithology also predominates in the lower part of the highstand systems tract (HST). A more detailed view of this systems tract is showed in photograph (B). The white bar in (A) shows the location of close-up (B) (the length of this bar is $40 \mathrm{~m}$ ). The upper part of these highstand deposits consists of oolitic sand bars which prograde on the shallow subtidal rhythmic series (the surface of progradation is indicated by an arrow). (C) Distribution of the lowstand $(L S T)$ and transgressive systems tract $(T S T)$ in Sequence B. The approximate position of this photograph is indicated by the star on the right side of photograph (A). The main lithological features of this interval can be seen in section B, Fig. 3 . 

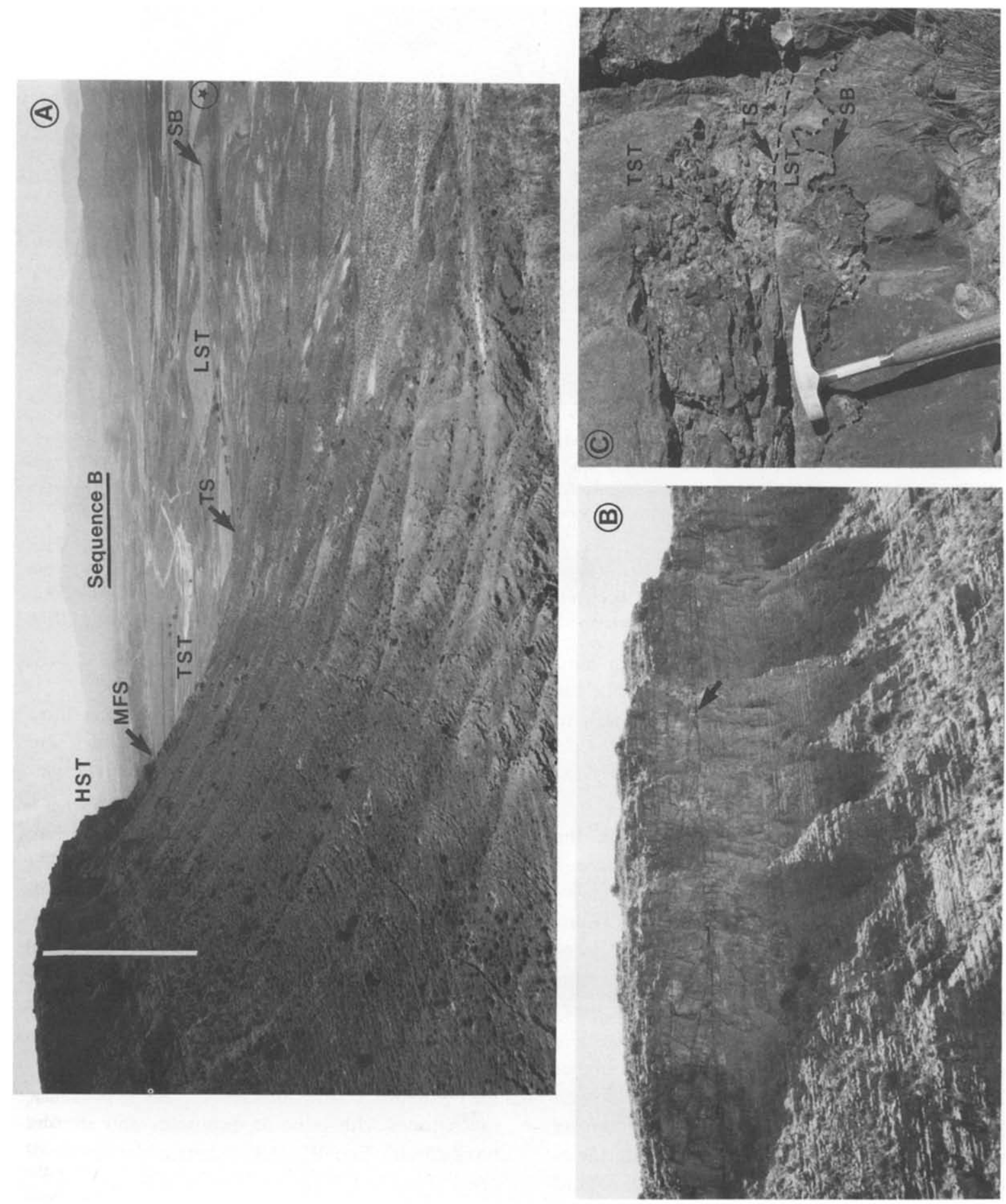


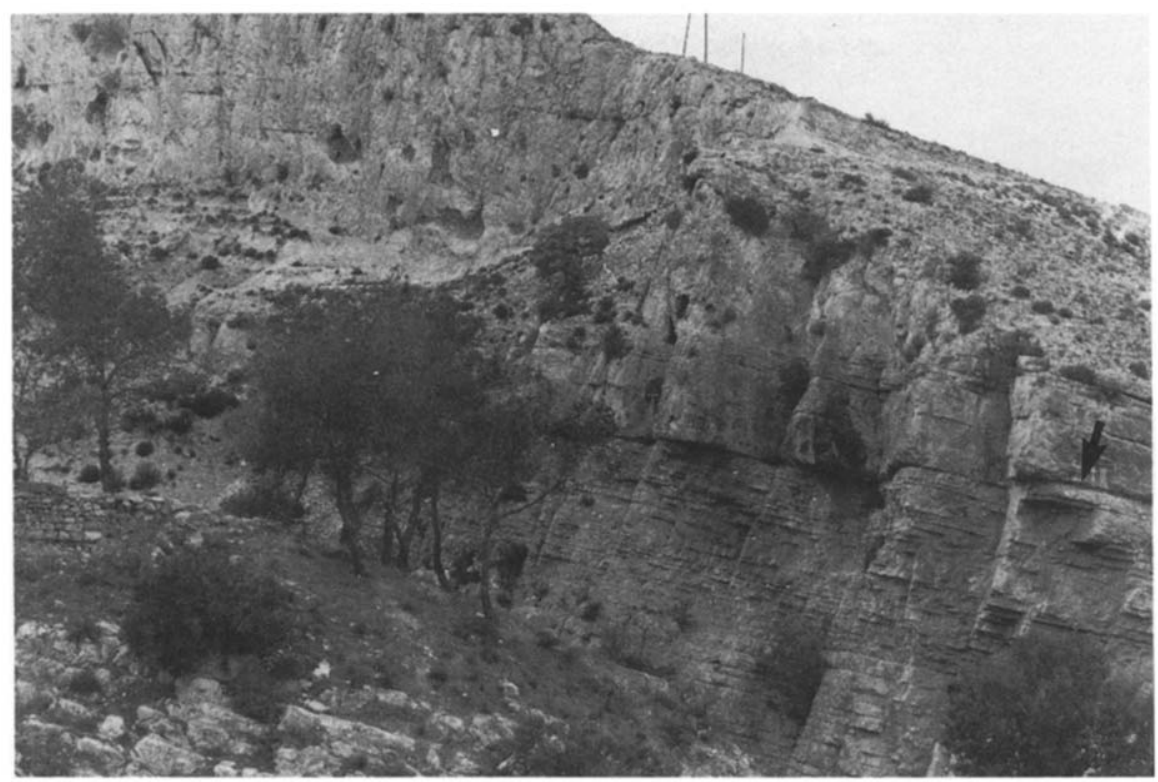

Fig. 6. The upper Sequence B boundary in the Mezalocha section (i.e., section 3 in Fig. 1). This unconformity consists of a planar surface which is indicated by the arrow. The unconformity separates the rhythmic series at the top of the Sequence B from the massive oncolite limestones corresponding to the Middle Tithonian. Those rhythmic series are a lateral equivalent of the oolitic grainstones located in more proximal areas (i.e., Ricla section, Fig. 5 (B)).

(see Fig. 3C). This facies is covered by a hard ground surface, rich in ferruginous-oxides. In the western areas, bioclastic facies (packstones to wackestones) prevail (Fig. 3D).

\section{Interpretation}

The burrowed planar surface overlaying the lowstand systems tract, or transgressive surface, forms the lower boundary of the transgressive systems tract. With the beginning of the Transversarium chronozone, a flooding event produces open marine conditions over the entire basin. This favours the deposition of ammonites and other stenohaline groups (e.g. sponges, crinoids, brachiopods) across the ramp. Topographic higher areas, that remained emerged during the Callovian and Lower Oxfordian, were also flooded during this event (i.e., Ejulve high). The bioclastic facies recorded in this areas shows a more shallow and energetic environment. The Transversarium biozone displays a condensed sedimentation and is interpreted as being deposited during the onset of this rapid rise of relative sea level.
Maximum flooding surface and highstand systems tract

\section{Field data}

The condensed ammonite and sponge facies of the former unit is covered by a widespread hard ground. Over this surface, a wedge-shaped depositional system developed (Fig. 3). In the middle areas of the basin, this unit displays a decimetrethick alternation of glauconitic wackestones with ammonites, belemnites, forams, echinoids, sponges and brachiopods and interbedded glauconitic marls having a total thickness of up to $8 \mathrm{~m}$. In the proximal areas, this unit reaches a thickness of 60 $\mathrm{m}$, with marl and bioclastic facies prevailing (packstones with crinoids, echinoids and ahermatypic corals). Locally, clastic deltaic systems developed (Fig. 3A). Near the top of this unit and in these proximal areas, a local unconformity with a hiatus affecting the Bimammatum biozone ( $\mathrm{Hy}$ pselum subzone, see Corbalán and Meléndez, 1986) is present. 


\section{Interpretation}

The hard ground overlying the former condensed sections is interpreted as the maximum flooding surface, or lower boundary of the highstand systems tract. On this surface, the recorded materials display a wedge-shaped progradational geometry, interpreted as being deposited during a highstand episode. The clastic sediments present northwest of this progradational system have been related with the local uplift of the emerged, northern marginal areas ("Ebro Massif", in Bulard, 1972). The glauconitic marls and ammonite condensed facies, present at the distal edge, are indicative for the basinward starvation of this depositional system. The local unconformity, present in some parts in the proximal areas, is regarded as a minor discontinuity, developed previously to the more widespread unconformity at the top of this unit and therefore interpreted as the boundary between the Oxfordian and Kimmeridgian Sequences

\section{Kimmeridgian Sequence}

\section{Sequence boundary and lowstand system tract}

\section{Field data}

An unconformity with a hiatus partly affecting the upper part of the Planula biozone (uppermost Oxfordian) separates the Oxfordian and Kimmeridgian Sequences (Fig. 2). In the western areas of the basin, siliciclastic and bioclastic sediments of the top of the Oxfordian Sequence are capped by an uneven, locally erosional and ferruginous surface and are overlain by the basal deposits of the Kimmeridgian Sequence (i.e., bivalve wackestones, see Fig. 4A). Eastwards, the sequence boundary is represented by a planar surface rich in ferruginous particles and overlain by marls. Here the associated hiatus is reduced or absent (Fig. 4B). These marls, containing ostracods, bivalves and plant remains, have a maximum thickness in the basin's depocentre of up to $60 \mathrm{~m}$. Towards the top they contain siliciclastic graded beds of 0.1 to $1 \mathrm{~m}$ thickness. In the more distal areas, these marls are reduced (less than $2 \mathrm{~m}$ thick, Fig. 4C) or absent. This marly depositional system, developed between the uppermost Oxfordian and the lowermost Kimmeridgian, is generally absent in the western areas.

\section{Interpretation}

The lower boundary of the Kimmeridgian Sequence is an unconformity with an associated hiatus in the western or proximal areas of the basin. The uneven and ferruginous surface in the most proximal areas is regarded as evidence for subaerial exposition. Basinward, this surface passes into an even and conformable surface, with no evidence for subaerial exposure. The marls with ostracodes and plant remains immediately above this even surface suggest a shallow, restricted subtidal, environment. Wave energy is dampened on the laterally extensive and shallow muddy ramp causing low-energy and partially anoxic conditions in the more interior part. In the proximal areas, graded siliciclastic beds present in the top of this unit are interpreted as inundite deposits (i.e., clastic material spread across the proximal marine areas from the emerged adjacent areas, see also Seilacher, 1985). This marly depositional system, interpreted as the lowstand systems tract of the Kimmeridgian Sequence, displays a progradational wedge-shaped geometry (Fig. 4).

Transgressive surface and transgressive systems tract

\section{Field data}

Along the eastern side of the basin, the marls of the lower unit are overlain by a series of ammonite wackestones via a sharp even surface. This surface contains Lower Kimmeridgian ammonites (i.e., Platynota biozone, Desmoides subzone). The overlaying ammonite wackestones facies are Lower Kimmeridgian in age and are generally reduced in thickness (Fig. 4C). The three Lower Kimmeridgian biozones, i.e., Platynota, Hypselocyclum and Divisum biozones, have mean thicknesses, in this eastern areas, of respectively 8,2 and $1 \mathrm{~m}$ (see Atrops and Meléndez, 1985), therefore indicating a reduction in thickness towards the top of the Lower Kimmeridgian. A widespread, well-developed hard ground covers this ammonite facies. In the middle of the basin, the boundary is transitional into a marl and mudstone alternation. In these areas, the Lower Kimmeridgian section 
measures up to $60 \mathrm{~m}$ with rhythmic micrites (mudstones with crinoids, bivalves and scattered ammonites) and marl alternations. This alternation passes landward into marls with plant remains, siliciclastic grains, crinoids and scattered bivalves. Towards the top of the Lower Kimmeridgian section, the marls are covered by the rhythmic micrites and marls facies.

Near the westernmost edge of the basin, when the uppermost Oxfordian marls are absent, this surface may merge with the previous described uneven boundary between siliciclastics and bivalve wackestones (Fig. 4A).

\section{Interpretation}

The even surface capping the lowstand systems tract marls is interpreted as the transgressive surface or the lower boundary of the overlying transgressive systems tract. This flooding episode involves the restoration of open marine conditions. The planar surface overlying the marls in the eastern and more distal areas, is interpreted as the transgressive surface (i.e., Platynota biozone, Desmoides subzone). The overlying ammonite wackestones are interpreted as condensed sections, deposited during an episode of rapid flooding of the basin. In the most proximal areas, the transgressive surface may coincide with the lower sequence boundary. This relative sea-level rise during the Lower Kimmeridgian produced a retrogradational facies geometry, as shown by the superposition of a micritic distal facies over more proximal marls (see Fig. 4).

Maximum flooding surface and highstand systems tract

\section{Field data}

The uppermost unit corresponds to the Upper Kimmeridgian and lowermost Tithonian. In the western areas, this unit can reach $60 \mathrm{~m}$ in thickness and is composed of a stacking of coralgal reefal complexes and oolitic sand shoals, that are overlying the previous lime-mudstones and marls via a gradual transitional surface. These oolitic grainstones and reefal facies pass eastward into a rhythmic series of marls and fossil wacke- to mudstones (benthic forams, green algae, brachiopods, crinoids, serpulids). In the easter areas, the base of this unit consists of marls with ammonites, changing towards the top into micritic limestones with scattered brachiopods, crinoids, forams, sponges and ammonites. In this eastern domain, the thickness of this unit is between 60 and $80 \mathrm{~m}$. The top of this unit is the upper Kimmeridgian Sequence boundary, that corresponds to an unconformity in the most proximal areas, showing locally an angular unconformable relationship with overlying uppermost Jurassic continental deposits (Bulard, 1972; Aurell, 1990; Alonso and Mas, 1990). Basinward, this boundary is a transitional change (i.e., correlative conformity) (Aurell, 1990).

\section{Interpretation}

The lower boundary of the highstand systems tract is regarded as the maximum flooding surface. This surface marks the change from a retrogradational to aggradational and progradational facies architecture, corresponding to the change from transgressive to highstand systems tracts (Fig. 4B). The hard ground surface capping the condensed facies in the eastern part of the ramp is interpreted as the maximum flooding surface of the Kimmeridgian Sequence. The proximal reefal and oolitic facies that are prograding over the micritic, more distal facies, were deposited during this highstand of sea-level episode.

\section{Discussion}

General characteristics of the Upper Jurassic systems tracts

The main features in systems tracts and bounding surfaces observed in the Upper Jurassic of the Iberian Chain are summarized in Fig. 7 . Sequence boundaries are unconformities with associated hiatus, at least in the proximal areas of the basin, where this surface is marked by an association of features indicative of subaerial exposition: highly irregular surfaces interpreted as karstic in origin, ferruginous crusts and truncational surfaces capping shallow marine deposits as oolitic grainstones. Basinward, this unconformity can be absent, passing into a correlative conformity, but the position of the sequence boundary is denoted by 


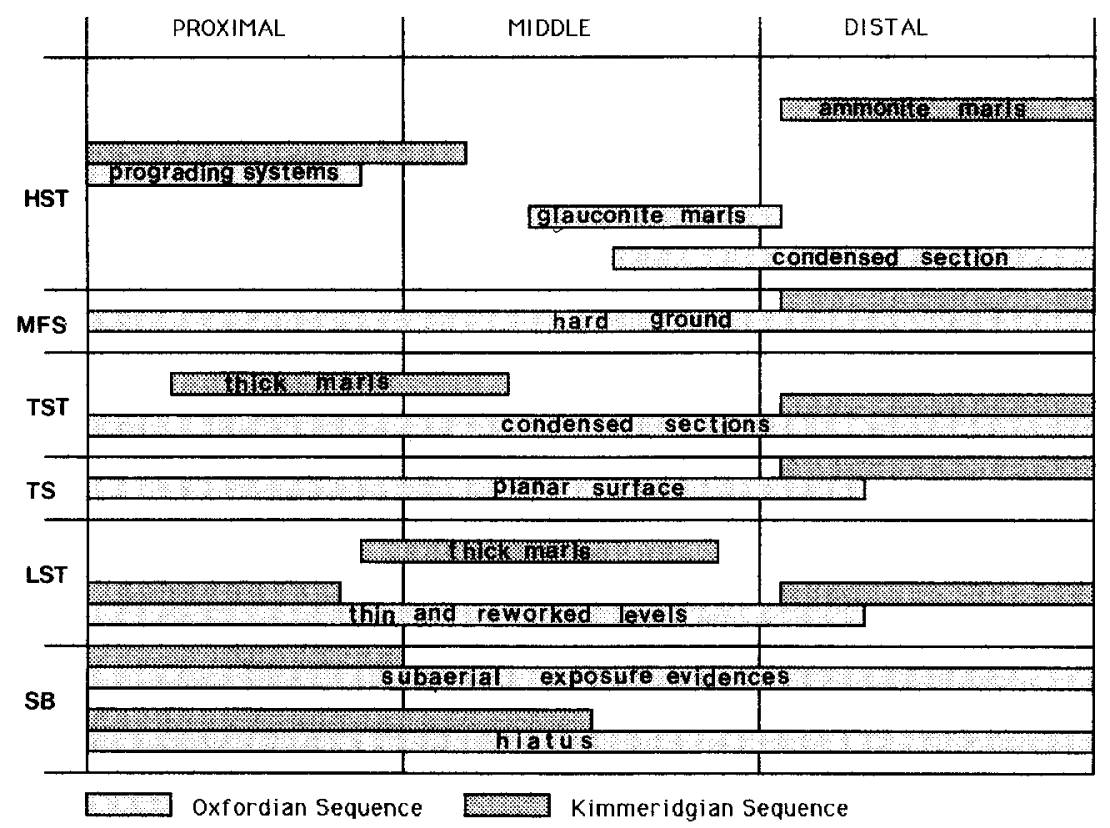

Fig. 7. Summary of the main features observed in the systems tracts and bounding surfaces in the Upper Jurassic carbonate ramps (Iberian Chain) showing their distribution across the proximal, middle and distal areas of the basin.

biostratigraphic data (i.e., ammonite assemblages).

Lowstand systems tract deposits are normally reduced to a thin reworked level filling unconformity surfaces, because the flat and even ramp topography does not leave accommodation following the relative sea-level fall. This situation is represented by the reworked levels with ferruginous and phosphatic fossil moulds, lithoclasts and ferruginous ooids and pisoids in the Oxfordian Sequence, or by the thin, ostracod-rich, marls in the distal areas of the basin in the Kimmeridgian Sequence. However, the lowstand systems tract deposits of the Kimmeridgian Sequence in the middle part of the basin are thick and well-developed. The main factor suggested to explain this difference is the rate of subsidence, creating accommodation space during deposition. Whereas the Lower Oxfordian is a tectonically stable episode, with few creation of new accommodation space, at the boundary between the Oxfordian and Kimmeridgian Sequence (i.e., uppermost Oxfordian) considerable accommodation space was created as a consequence of the tectonic reactivation of basement faults (Salas, 1987). This tectonic reactivation phase involved both the generation of a subsiding furrow in the middle part of the ramp and the uplift of the most western proximal areas (Aurell and Meléndez, 1989; Aurell, 1990). High sedimentation rates with clastic input during this lowstand episode generated a prograding wedge.

The transgressive surface is planar and marks a sharp boundary between the restricted and open marine fossil assemblages. This surface can be burrowed showing traces of Diplocraterium (Oxfordian Sequence). In the middle part of the basin, in the Kimmeridgian Sequence, the transgressive surface can be absent indicating a transitional change from restricted to more open marine conditions. In the proximal areas it may merge with the sequence boundary. The transgressive systems tracts show sedimentary condensation, at least in the distal areas of the basin, where ammonite wackestones prevail. Condensation increases towards the top of this system tract. The sedimentary condensation is interpreted as a response to high rates of accommodation space creation in combination with low rates of carbonate production (i.e., ramp starvation).

On this condensed section there is a hard ground surface which corresponds to a maximum flooding surface. This surface marks the boundary between the retrogradational and progradational 
assemblages, and can be a transitional boundary in the proximal and middle areas of the basin (Kimmeridgian Sequence). The highstand systems tract in the Oxfordian Sequence develops a wedge-shaped progradational geometry, with local occurrence of clastic sediments in the proximal areas. In the distal areas, the sedimentation is condensed, with glauconite marls facies present. The Kimmeridgian Sequence highstand systems tract displays oolitic and reefal prograding complexes in the proximal areas and ammonite marls in the distal ones. This system tract has an aggradational component, with no condensed section in the distal areas, that has been related to the high carbonate production in the entire basin that kept pace with and even exceeded the rate of creation of accommodation, mainly caused by tectonic subsidence.

\section{Origin of accommodation}

Sequence stratigraphic models consider the subsidence history as a linear and continuous process across the basin. As a consequence, variations in the accommodation, expressed as unconformities or flooding surfaces, are regarded as produced by superimposed cyclic variations of sea level. The boundaries of the depositional sequences, unconformities with hiatus and subaerial exposure evi- dence at least in the proximal areas of the basin, are suggested to be related to relative sea-level falls. The persistence of some unconformities from one basin to another has led to the idea that some, or even most, of such boundaries are eustatic in origin (Haq et al., 1987).

In an intracratonic basin like the Iberian basin, the subsidence normally has a complex history, with irregular distribution in space and in time. Therefore, in our study, we cannot assume a direct eustatic relationship between eustacy and sequences and systems tracts boundaries as it is proposed in the sequence stratigraphic approach by Vail et al. (1987). Instead, the distribution of facies within a sequence defining systems tracts is considered to be a result of the interplay between the accommodation and sedimentary supply (and/or carbonate production). The accommodation depends on eustacy and subsidence rates.

The comparison between the position of the unconformities detected in the Iberian Chain and those proposed as global in origin (Haq et al., 1987; Hallam, 1988) can yield some idea on the interplay of the eustacy and subsidence, creating this accommodation. Figure 8 shows the unconformities and maximum flooding marine events recognized in the Central Iberian Chain during the uppermost Callovian to Lower Tithonian, as well as the global eustatic curves proposed for this
A

B

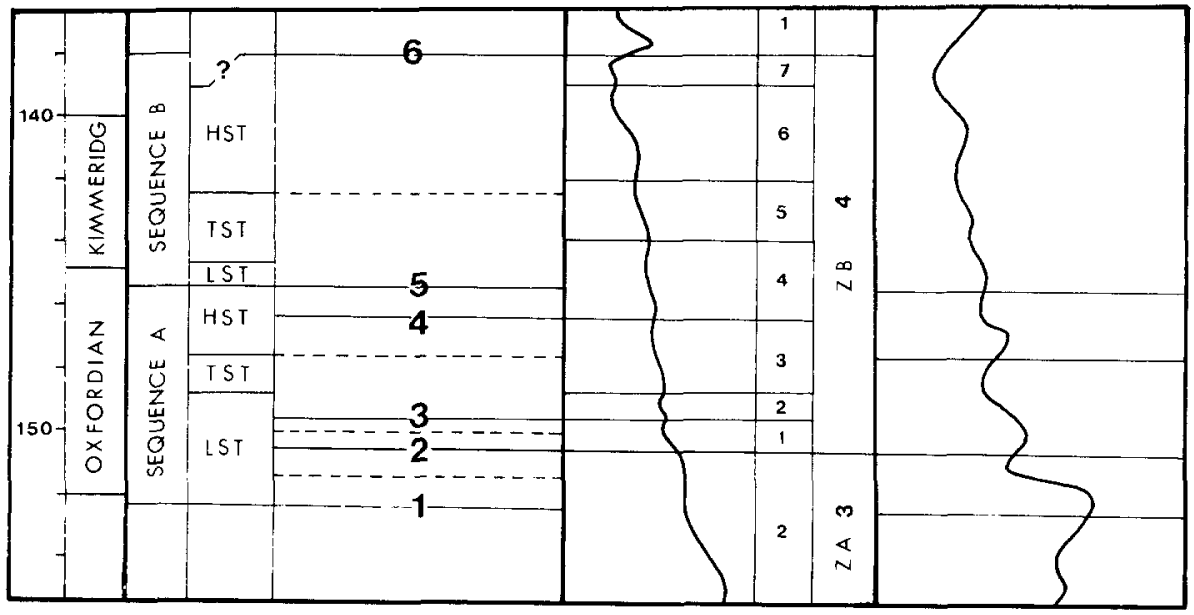

Fig. 8. Stratigraphic position of the unconformities (continuous lines) and maximum flooding surfaces (dashed lines) recorded in the Oxfordian-Kimmeridgian of the Central Iberian Chain (A), compared with the global curves of Haq et al. (1987) and Hallam (1988) 
same chronostratigraphic interval by $\mathrm{Haq}$ et al. (1987) and Hallam (1988). In the Iberian Chain, some unconformities are recognized throughout the entire basin, and are interpreted as sequence boundaries (i.e., numbers 1,5 and 6 ). In the Oxfordian Sequence we have considered three minor unconformities. The two lower ones (i.e., numbers 2 and 3) correspond to the boundaries of the two punctuated highstands of the sea level developed during the lowstand systems tract (i.e., lower Cordatum and lower Plicatilis chrons); the upper one is a minor unconformity located at the top of the highstand systems tract (intra-Bimammatum biozone, i.e., number 4).

Towards the top of the Callovian there is an important regression, in many European basins related to the formation of ferruginous ooids. Examples of a similar situation to the Iberian basin are in Borgougne (Floquet et al., 1989) and in the Swiss Jura basin (Gygi and Persoz, 1986). In both cases, like in the Hallam proposal, an uppermost Callovian unconformity is reported (i.e., Lamberti biozone). This unconformity corresponds to the lower boundary of the Oxfordian Sequence in the Iberian Chain. However, this sequence boundary is not found in the Exxon curve (Haq et al., 1987). This discrepancy may be due to a difference of interpretation since the bed with ferruginous ooids of the Callovian-Oxfordian boundary in the Paris basin was considered by Vail et al. (1987) as a condensed section (i.e., cycle ZA-3.2, in Fig. 6). However, in this curve we do find the other "lower order" unconformities of the Oxfordian Sequence. A similar position for the two unconformities detected at the end of the Oxfordian in the Iberian Chain, is reported in the curve by Hallam (1988). The upper boundary of the Oxfordian Sequence is not recognized in the Exxon curve.

No intermediate unconformities are found within the Kimmeridgian Sequence in the Iberian Chain. However, numerous studies have proposed a division of the Kimmeridgian into several sequences in other European basins (e.g., Gygi and Persoz, 1986; Haq et al., 1987; Hallam, 1988).

Assuming the subsidence figures deduced by Salas (1987) for the Oxfordian and Kimmeridgian Sequences we may expect a larger role of the eustacy creating the accommodation during the
Oxfordian, when the subsidence was much lower. The calculated subsidence rates for both sequences in the depocenter basin (i.e., Maestrat, Eastern Iberian Chain) is 0.2 and $4.3 \mathrm{~cm} / 1,000 \mathrm{yr}$, respectively (backstripping techniques, Bond and Kominz, 1984). Similar rates were deduced by Aurell (1990) in the Central Iberian Chain applying the formula proposed by Cant (1989). Tectonic reactivation of basement faults, occurring during the uppermost Oxfordian, implies a predominant role of the tectonic subsidence in creating the larger accommodation space in the Kimmeridgian Sequence. The eustatic role during the Oxfordian Sequence would be denoted by the sensible coincidences between the unconformities recorded in the Iberian Chain and those proposed in the Exxon and Hallam curves. On the other hand, none of the unconformities proposed during the Kimmeridgian are recorded in the Iberian Chain. We can assume a model for the Kimmeridgian Sequence in which the creation of accommodation is mainly a function of the subsidence. In this subsidence-dominated scenario, possible superimposed eustatic signals would be diluted and would not appear in the sediment record.

The question remains as to why there is no total correlation between the unconformities recorded during the Oxfordian in the Iberian Chain and those hypothesized in the global eustatic curves. Besides the above-mentioned problems of interpretation (e.g. ferruginous oolitic bed, Vail et al., 1987), it should be noted that several authors have questioned the existence of global third-order cycles. Apart from glacioeustatic variations, no global mechanisms are found which would produce rise or fall rates such as those defined by these third-order cycles. On the contrary, these eustatic changes may correspond to local tectonic phenomena (i.e. tectono-eustatic movements) which could affect a single basin or a series of genetically linked basins (e.g., Miall, 1986; Kenter et al., 1990). It is interesting to recall the observations of Cloething (1988) which show that changes in the stress fields in intraplate zones can lead to relative regional sea-level variations with rates of over $1 \mathrm{~cm} / 1,000 \mathrm{yr}$. According to the available data, the unconformities recognized in the Iberian Chain in periods of very low subsidence (i.e., 
Oxfordian Sequence) would correspond to regional tectono-eustatic changes, affecting at least several European basins. However, a more systematic study of basins with a well-documented subsidence history and located in separated tectonic regions is needed in order to test the geographical extent of these unconformities.

\section{Conclusions}

Sedimentologic fieldwork and the analysis of biostratigraphic data allowed the recognition and description of systems tracts within two different sequences, deposited in a low-angle carbonate ramp setting of an Upper Jurassic age in the central Iberian Chain, Spain. The Oxfordian Sequence, with a negligible initial topography, was formed during a period of tectonic stability with little creation of accommodation and is characterized by thin and condensed sediment packages. During deposition of the Kimmeridgian Sequence, rates of creation of accommodation were considerably higher and resulted in the formation of a different set of systems tracts. The descriptions of sedimentary features of the systems tracts for the two sequences formed during periods of significant different accommodation rates on a low-angle carbonate ramp, are suggested to be used as tools for the recognition of systems tracts patterns within sequences in comparable depositional settings.

The identification of systems tracts in low-angle carbonate ramps is mainly based on the analysis of the facies associations across the proximal, middle and distal areas of the ramp, and therefore is often based on the sedimentological interpretation. However, without extensive and precise data these assignments may be arbitrary. In the Iberian Chain, this uncertainty is substantially reduced by the numerous outcrops and the precise biostratigraphic data.

\section{Acknowledgements}

Financial support was provided by M.E.C. (Ministerio de Educación y Ciencia, Spain) and D.G.A. (Diputación General de Aragón). I am indebted to Alfonso Meléndez and Guillermo
Meléndez (Universidad de Zaragoza), Ramón Mas (Universidad Complutense Madrid) and Ramón Salas (Universitat Central Barcelona) for fruitful discussions and comments. This paper was written during a M.E.C. postdoctoral fellowship under the supervision of Robert N. Ginsburg, at the Comparative Sedimentology Laboratory, University of Miami. The author also thanks Jeroen Kenter for critic comments during the review of earlier versions of the manuscript, and two anonymous reviewers for improving the manuscript.

\section{References}

Alonso, A. and Mas, J.R., 1990. El Jurásico superior en el sector Demanda-Cameros (La Rioja-Soria). Cuad. Geol. Ibérica, 14: 173-198.

Atrops, F. and Meléndez, G., 1985. Kimmeridgian and lower Tithonian from the Calanda-Berge area (Iberian Chain, Spain): some biostratigraphic remarks. Proc. 1st Int. Symp. Jurassic Stratigraphy, Erlangen, 1984, 1: 377-392.

Aurell, M., 1990. El Jurasico superior en la Cordillera Iberica Central (provincias de Zaragoza y Teruel). Analisis de cuenca. Tesis Doctoral, Dpto. Geología, Univ. de Zaragoza, Servicio Publicaciones Univ. de Zaragoza Ed., 389 pp.

Aurell, M. and Meléndez, A., 1989. Influencia de la falla del Jiloca durante la sedimentación del Malm en la Cordillera Ibérica Central (prov. de Teruel, relación tectónica-sedimentación). Rev. Soc. Geol. España, 2: 65-75.

Aurell, M., Meléndez, A. and Meléndez, G., 1990a. Caracterizacion de la Secuencia Oxfordiense en el sector central de la Cordillera Iberica. Geogaceta, 8: 73-76.

Aurell, M., Meléndez, G. and Salas, R., 1990b. On the origin of Lower and Middle Oxfordian Ironstone facies in the Iberian Chain (NE Spain). 13th Int. Sediment. Congr., Nottingham, Abstr., pp. 29-30.

Bond, G.C. and Kominz, M.A., 1984. Construction of tectonic subsidence curves for the early Paleozoic migeocline, southern Canadian Rocky Mountains: implications for subsidence mechanisms, age of breakup, and crustal thinning. Geol. Soc. Am. Bull., 95: 155-173.

Bulard, P.F., 1972. Le Jurassique moyen et supérieur de la Chaine Ibérique sur la bordure du bassin de l'Ebre (Espagne). Thèse de doctorat, Fac. Sciences, Univ. Nice, $702 \mathrm{pp}$.

Calvet, F., Tucker, M.E. and Henton, J.M., 1990. Middle Triassic ramp systems in the Catalan Basin, northeast Spain: facies, systems tracts, sequences and controls. Spec. Publ. Int. Assoc. Sedimentol., 9: 79-108.

Cant, D.J., 1989. Simple equations of sedimentation: applications to sequence stratigraphy. Basin Res., 2: 73-81.

Cloething, S., 1988. Intraplate stresses: a tectonic cause for third-order cycles in apparent sea level? Soc. Econ. Paleontol. Mineral., Spec. Publ., 42: 19-30. 
Corbalán, F. and Meléndez, G., 1986. Nuevos datos bioestratigráficos sobre el Jurásico superior del sector central de la Cordillera Ibérica. Acta Geol. Hip., 21-22: 555-560.

Floquet, M., Laurin, B., Laville, P., Marchand, J.C., Menot, J.C., Pascal, A. and Thierry, J., 1989. Les systèmes sédimentaires Bourguignons d'âge Bathonien terminal-Callovien. Bull. Centres Rech. Explor. Prod. Elf-Aquitaine, 13 (1): 133-165.

Flügel, E., 1982. Microfacies Analysis of Limestones. Springer-Verlag, Berlin, 632 pp.

Fontana, B. and Meléndez, G., 1990. Caracterización bioestratigráfica de la Biozona Transversarium (Oxfordiense medio) en el sector oriental de la Cordillera Ibérica. Geogaceta, 8: $76-78$.

Gygi, R.A. and Persoz, F., 1986. Mineralostratigraphy, lithoand biostratigraphy combined in correlation of the Oxfordian (late Jurassic) formations of the Swiss Jura range. Eclogae Geol. Helv., 79 (2): 385-454.

Hallam, A., 1988. A reevaluation of Jurassic eustasy in the light of new data and the revised Exxon curve. Soc. Econ. Paleontol. Mineral., Spec. Publ., 42: 261-274.

Haq, B.H., Hardenbol, J. and Vail, P.R., 1987. Chronology of fluctuating sea levels since the Triassic. Science, 235: 1156 1167.

Kenter, J.A.M., Reymer, J.J.G., Van der Straaten, H.C. and Peper, T., 1990. Facies patterns and subsidence history of the Jumilla-Cieza region (southeastern Spain). Sediment. Geol., 67: 263-280.

Meléndez, G., Aurell, M., Fontana, B. and Lardiés, D., 1990. El tránsito Dogger-Malm en el sector nororiental de la Cordillera Ibérica: análisis tafonómico y reconstrucción paleogeográfica. Comunic. Reunión de Tafonomía y Evolución, Univ. Comp. Madrid, 1990, pp. 221-229.

Meléndez, G. and Brochwicz-Lewinskii, W., 1983. El Oxfordiense inferior en el sector central de la Cordillera Ibérica (S Zaragoza-N Teruel). Teruel, 69: 211-226.

Miall, A.D., 1986. Eustatic sea level changes interpreted from seismic stratigraphy: a critique of the metology with particular reference to the North Sea Jurassic record. Bull. Am. Assoc. Pet. Geol., 70: 131-137.

Nahon, D., Carozzi, A.V. and Parron, C., 1980. Lateritic weathering as a mechanism for the generation of ferruginous ooids. J. Sediment. Petrol., 50: 1287-1298.

Salas, R., 1987. El Malm i el Cretaci inferior entre el Massís de Garraf i la Serra d'Espadá. Analisi de conca. Tesis doctoral, Universitat de Barcelona, Dpto. de Geoquímica, Petrología i Prospecció geológica, 3, 345 pp.

Salas, R., 1990. Evolución estratigráfica secuencial y tipos de plataformas de carbonatos del intervalo OxfordienseBerriasiense en las Cordilleras Ibérica Oriental y Costero Catalana Meridional. Cuad. Geol. Ibérica, 13: 121-157.

Sarg, J.F., 1988. Carbonate sequence stratigraphy. In: Wilgus et al. (Editors), Sea Level Changes: An Integrated Approach. Spec. Publ. S.E.P.M., 42: 155-181.

Scholle, P.A., Bedout, D.G. and Moore, C.H. (Editors), 1983. Carbonate Depositional Environments. Am. Assoc. Pet. Geol. Mem., 33, 708 pp.

Seilacher, A., 1985. Storm beds: their significance in event stratigraphy. In: E. Seibold and J.D. Meulenkamp (Editors), Stratigraphy: Quo Vadis? A.A.P.G. Stud. Geol., 16: 49-54.

Siehl, A. and Thein, J., 1978. Geochemische Trends in der Minette (Jura, Luxemburg/Lotharingen). Geol. Rundsch., 67: 1052-1077.

Vail, P.R., Mitchum, R.M. and Thompson, S., 1977. Seismic stratigraphy and global changes of sea level, 4. Global cycles of relative changes of sea level. In: Ch.E. Payton (Editor), Seismic Stratigraphy. Applications to Hydrocarbon Exploration. Am. Assoc. Pet. Geol. Mem., 26: 8397.

Vail, P.R., Colin, J.P., Chene, J., Kuchly, J., Mediavilla, F. and Trifilief, F., 1987. La stratigraphie sequentielle et son application aux corrélations chronostratigraphiques dans le Jurassique du bassin de Paris. Bull. Soc. Géol. Fr., (8), III, 7: $301-321$.

Van Wagoner, J.C., Possamienter, H.W., Mitchum, R.M., Vail, P.R., Sarg, J.F., Loutit, T.S. and Hardenbol, J., 1988. An overview of the fundamentals of sequence stratigraphy and key definitions. In: Sea Level Changes-An Integrated Approach. S.E.P.M. Spec. Publ., 42: 39-45.

Wilson, J.L., 1975. Carbonate Facies in Geologic History. Springer-Verlag, Berlin, 471 pp. 